\title{
Czynniki optymalizacji struktury zatrudnienia pracowników stałych i tymczasowych
}

\section{Optimization factors of permanent and temporary staff structure}

\author{
Beata Skowron-Mielnik \\ Uniwersytet Ekonomiczny w Poznaniu, e-mail: beata.skowron-mielnik@ue.poznan.pl \\ Dariusz Prokop \\ Uniwersytet Ekonomiczny w Poznaniu, e-mail: darpro21@gmail.com
}

Grzegorz Wojtkowiak

Uniwersytet Ekonomicznyw Poznaniu, e-mail: g.wojtkowiak@ue.poznan.pl

\begin{abstract}
Streszczenie
Niniejszy artykuł dotyczy problematyki elastyczności organizacji w zakresie procesów produkcyjnych i zatrudnienia. Przesłanką podjęcia tematu było zauważane w praktyce gospodarczej rosnące zapotrzebowanie na elastyczną siłę roboczą, którego przejawem jest wzrost zatrudnienia pracowników tymczasowych. W przypadku podmiotów produkcyjnych rodzi to jednak równie wiele korzyści co problemów. Celem opracowania stało się więc zidentyfikowanie czynników optymalizacji struktury zatrudnienia pracowników stałych i tymczasowych. W związku z tym uznano, że odpowiednią metodą przeprowadzenia badań empirycznych będzie studium przypadku - do analizy wybrano przedsiębiorstwo produkcyjne, które wykorzystuje pracę tymczasową, jednak sytuacja ta stwarza problemy zarządzania pracownikami zarówno tymczasowymi, jak i stałymi. W wyniku przeprowadzonych badań wskazano na trzy istotne czynniki: koszt pracy, wydajność pracy, doświadczenie zawodowe. Zidentyfikowane czynniki i sposób ich oddziaływania stwarzają podstawę do podjęcia próby zbudowania modelu optymalizacji elastycznej struktury zatrudnienia.
\end{abstract}

Słowa kluczowe: optymalizacja zatrudnienia, koszty elastyczności zatrudnienia, produktywność pracowników tymczasowych, elastyczność produkcji.

\begin{abstract}
This article concentrates on the subject of flexibility of organizations in the area of production and employment processes. The premise for researching this topic was increasing demand for flexible workforce which could be observed in the business practice, the main symptom of which was the growth of temporary employees. In case of production entities it generates many advantages, but some disadvantages as well. Therefore, the aim of this analysis is to identify the factors of optimalization of employment structure of permanent and temporary employees. In reference to the above, the author recognized that the most appropriate method of empirical research would be the case study - the production entities that were chosen for this analysis use temporary workforce, but this situation causes problems in employee management, as well with temporary and permanent employees. As a result of research three significant factors were indicated: costs of work, efficiency of work and work experience. The identified factors and their influence create the base for an attempt to build an optimization model of flexible employment structure.
\end{abstract}

Keywords: employment optimization, costs of employment flexibility, productivity of temporary employees, production flexibility. 


\section{Wstęp}

Niektóre branże, takie jak budowlana czy turystyczna, tradycyjnie związane są z wysoką sezonowością działania - jest to jednak dla nich tendencja planowana i względnie przewidywalna. W przypadku produkcji przemysłowej konieczność sprostania wymogom coraz bardziej zmieniającego się rynku nastręcza dodatkowych problemów i wymusza wprowadzenie zmian zarówno technologicznych, jak i organizacyjnych.

Konieczność kształtowania elastyczności wynika z niepewności dotyczącej funkcjonowania w wielu branżach i skutkuje brakiem możliwości planowania długo- i średnioterminowego. Wahania produkcji wynikają także z coraz bardziej przyspieszonych procesów w całym przedsiębiorstwie. Wdrażanie takich koncepcji i rozwiązań jak just-in-time czy lean production przenosi skutki wahań sprzedaży na zmienność produkcji. Takie metody zapewniają ograniczenie stanów magazynowych, zmniejszenie wymaganego zaangażowania kapitałowego, utrudniają jednak planowanie i organizację produkcji.

Elastyczność rozwiązań technicznych umożliwiających zmienną produkcję dla większości branż jest z założenia kapitałochłonna - wymaga dodatkowych inwestycji i rodzi koszty niewykorzystanych mocy. Równocześnie sporym wyzwaniem stają się rozwiązania organizacyjne pozwalające na dopasowanie wielkości zatrudnienia do zadań produkcyjnych. Możliwość wprowadzania pracy zmianowej, wydłużonego okresu rozliczeniowego czasu pracy czy zatrudniania w ramach nadgodzin nie zawsze pozwala na dopasowanie zasobów kadrowych do zmian - stąd też rośnie popularność zatrudniania pracowników tymczasowych i kontraktowych. Istotne jest jednak racjonalne ukształtowanie relacji między liczbą pracowników tymczasowych i stałych tak, żeby zapewnić przedsiębiorstwu elastyczność, ale jednocześnie nie zdestabilizować załogi oraz nie pogorszyć efektywności pracy. Problem badawczy podjęty w niniejszym opracowaniu można zatem sformułować następująco: od czego zależy struktura zatrudnienia pracowników stałych i tymczasowych oraz jak należy ją kształtować, dążąc do optymalizacji kosztowej i efektywnościowej?

Celem tego artykułu jest przedstawienie czynników optymalizacji struktury zatrudnienia pracowników stałych i tymczasowych. Zidentyfikowanie ich stworzy podstawę do podjęcia próby zbudowania modelu optymalizacji elastycznej struktury zatrudnienia, który będzie przedmiotem dalszych publikacji autorów.

\section{Zatrudnienie tymczasowe $w$ elastycznym przedsiębiorstwie}

Elastyczność przedsiębiorstwa jest zagadnieniem rozważanym od wielu lat, jednak koncepcja ta ewoluowała - od pojmowania jej jako zdolności organizacji do dopasowywania się do zmiennych warunków otoczenia do roli czynnika redukującego wpływ tych zmian na organizację, co wskazuje na jej zarówno reaktywny, jak i proaktywny wymiar [De Toni, Tonchia 1998; Volberda 1998; Golden, Powell 2000; Johnson i in. 2003; Krupski (red.) 2005; Kasiewicz i in. 2009; Eapen 2010; Sushil, Connell, Burgess 2016]. Elastyczność ma zatem umożliwiać podejmowanie działań w celu uniezależnienia się organizacji od wpływów otoczenia, ale także zwiększenia zdolności oddziaływania na nie. Z czasem uznano jednak, że elastyczność nie jest wystarczającą cechą, ponieważ stanowi odpowiedź na przewidywalne zmiany w ramach rutynowych procedur i zastąpiono ją zwinnością (agility). Ta z kolei wiąże się z innowacyjnymi reakcjami na nieprzewidywalne zmiany w dynamicznym otoczeniu, szczególnie odnoszonymi do sytuacji przedsiębiorstw produkcyjnych [Zhang, Sharifi 2001; Trzcieliński 2011; Sajdak 2015].

Powyższe koncepcje wpłynęły na uksztaltowanie się elastycznego zarządzania zasobami ludzkimi, traktowanego jako paradygmat nowoczesnej gospodarki i kluczowa kompetencja potrzebna do strategicznej adaptacyjności tego zasobu [Bąk-Grabowska 2016, s. 62]. „Elastyczne zarządzanie kapitałem ludzkim polega na stwarzaniu możliwości swobodnego wyboru różnych kombinacji zasobów (rzeczowych i finansowych) z kapitałem ludzkim" [Juchnowicz 2016, s. 21]. Kluczowym elementem elastyczności zasobów ludzkich z praktycznego punktu widzenia jest elastyczność ilościowa, rozumiana jako zdolność dostosowania potencjału pracy mierzonego liczbą pracowników i/lub liczbą godzin pracy do pracochłonności działań przedsiębiorstwa w danym okresie. Ta zdolność dopasowania ilościowego wydaje się zasadnicza z punktu widzenia organizacji, ponieważ jest bardziej wymierna niż funkcjonalna czy finansowa, a jednocześnie wpływa na te dwa aspekty elastyczności. Odnosząc się do celów elastyczności zdefiniowanych przez Armstronga [2005, s. 348], należy stwierdzić, że sprzyja ona zwiększeniu elastyczności operacyjnej, optymalizacji wykorzystania kompetencji pracowników, zmniejszeniu kosztów zatrudnienia i redukcji personelu oraz zwiększeniu produktywności. Z punktu widzenia przedsiębiorcy daje zatem przekonanie, że nie musi płacić za niewykorzystany czas i kompetencje pracownika, ale też nie wykorzystuje go nadmiernie.

Elastyczność ilościowa obejmuje różnorodne formy organizacji czasu pracy (m.in. ruchomy czas pracy, pracę weekendową czy pracę niepełnowymiarową) i zatrudnienia - od nieelastycznych umów o pracę na czas nieokreślony, przez nieco bardziej elastyczną pracę tymczasową czy pracę na wezwanie, do bardzo elastycznych umów cywilnoprawnych czy kontraktowania pracy [Skowron-Mielnik 2012, s. 100; Juchnowicz 2016, s. 23]. Wymieniona tu praca tymczasowa (contingent work) zasługuje na szczególne rozważenie ze względu na wspomniany ekonomiczny i społeczny interes przedsiębiorcy. Można przez to pojęcie rozumieć także leasing pracowniczy, pracę sezonową, pracę dorywczą, a także zaliczyć do niej pracę w niepełnym wymiarze i zatrudnienie na czas określony. Jednak najbardziej rozpoznawalną formą stała się praca tymczasowa za pośrednictwem agencji pracy tymczasowej [Leighton i in. 2014, s. 35-44]. Z jednej strony, jest ona pracowniczym stosunkiem pracy, stwarza więc przesłanki stabilności dla pracownika, z drugiej - pozwala na elastyczne i mało obciążające kosztowo i organizacyjnie dla przedsiębiorcy pozyskanie pracownika, a relacja pracownika z pracodawcą ma w niej także dorywczy charakter.

Praca tymczasowa w Polsce, zgodnie z art. 2 pkt 3 Ustawy z dnia 9 lipca 2003 r. o zatrudnianiu pracowników tymczasowych [Ustawa... 2003], polega na wykonywaniu na rzecz danego pracodawcy - użytkownika zadań: 
- o charakterze sezonowym, okresowym, doraźnym,

- których terminowe wykonanie przez pracowników zatrudnianych przez pracodawcę - użytkownika nie jest możliwe,

- $\quad$ których wykonanie należy do obowiązków nieobecnego pracownika zatrudnianego przez pracodawcę - użytkownika.

Jednak nie charakter wykonywanych zadań przesądza o istocie pracy tymczasowej, ale specyfika samego zatrudnienia $w$ tej formie. „Ta forma elastycznego zatrudnienia charakteryzuje się wydajniejszym eksploatowaniem zasobów ludzkich. Może przyczyniać się to do redukcji kosztów związanych ze zbędnym stworzeniem, utrzymywaniem, a następnie także zlikwidowaniem stanowisk pracy, jak i bardziej efektywnym wykorzystaniem czasu pracy. W przeciwieństwie bowiem do pracownika zatrudnionego na pełny etat pracownik tymczasowy wykonuje prace jedynie w momencie, gdy rzeczywiście istnieje taka potrzeba" [Gołaszewska-Kaczan 2013]. Typowe sytuacje wykorzystania pracy tymczasowej to [Praca tymczasowa 2017]:

- okresy nasilenia produkcji,

- zastępstwo etatowego/stałego pracownika,

- prace związane z dużą rotacją pracowników,

- okolicznościowe akcje promocyjne,

- okres próbny przy zatrudnianiu nowego pracownika na etat,

- $\quad$ specyficzne prace związane z nieustannym wahaniem poziomu zatrudnienia,

- $\quad$ wykonanie prac nietypowych, które nie są związane z profilem działalności przedsiębiorstwa.

Jednocześnie jest to rozwiązanie występujące najczęściej w sektorze produkcyjnym [Makowski 2006, s. 81; Rynek agencji... 2017]: w Polsce w 2016 roku 73\% pracowników tymczasowych zatrudnionych było $\mathrm{w}$ przedsiębiorstwach produkcyjnych, $25 \% \mathrm{w}$ usługowych, $2 \% \mathrm{w}$ rolnictwie i $1 \%$ w budownictwie, wśród których przeważały duże przedsiębiorstwa. Z kolei główne kryteria decyzyjne związane z wyborem pracy tymczasowej jako metody optymalizacji zatrudnienia to: szybkość pozyskania nowego pracownika, dopasowanie liczby pracowników do potrzeb organizacji, obniżenie kosztów pracy. Należy zwrócić uwagę na to, że praca tymczasowa daje możliwość racjonalizacji również kosztów administracyjnych. Przedsiębiorstwo ponosi koszty związane jedynie z rzeczywistym czasem przepracowanym przez pracownika tymczasowego, pozostałe koszty (m.in. ZUS, koszty rekrutacji, obsługi kadrowo-płacowej) ponosi agencja [Gołaszewska-Kaczan 2013].

Standardowe przedsiębiorstwo - użytkownik to zatem duże przedsiębiorstwo produkcyjne, o znacznej zmienności działalności i relatywnie dużych kosztach pracy pracowników stałych. Ta charakterystyka wyraźnie wskazuje na zasadniczy problem podjęty w niniejszym artykule: praca tymczasowa jest uzupełnieniem czy też dopełnieniem zatrudnienia stałego, praktycznie nie istnieje bez podstawy w postaci stałej załogi. Modele elastycznego zatrudnienia - J. Atkinsona, Ch. Handy'ego, M. Gablety czy A. Pocztowskiego [Bąk-Grabowska 2016, s. 66-76] - zakładają wzrost elastyczności przez większy udział pracowników tymczasowych. Ale Ch. Handy przestrzega przed negatywnymi skutkami myślenia w wąskich kategoriach ekonomicznych, ponieważ wzrost produktywności nie powinien odbywać się kosztem redukcji stałych etatów i trudnościami w znalezieniu stałej pracy, bo to oznacza spadek kompetencji i siły nabywczej społeczeństwa. Podobnie jest w modelu J. Atkinsona, w przypadku którego zwraca się uwagę na pogarszanie sytuacji pracowników stałych (tymczasowy zagraża zajmowanej pozycji i zarobkom) i załamanie więzi między pracownikami stałymi i tymczasowymi. M. Gableta zwraca uwagę, poza niskim wynagrodzeniem i słabymi relacjami, na brak dbałości o rozwój pracowników tymczasowych, co przy znacznym ich zatrudnieniu obniża potencjał pracowniczy przedsiębiorstwa. Te spostrzeżenia wskazują na dodatkowe kryteria, które powinno uwzględnić przedsiębiorstwo, optymalizując zatrudnienie przez pracę tymczasową i decydując o zakresie jej wykorzystania. Jak jednak twierdzą P. Leighton, M. Syrett, R. Hecker i P. Holland [2014, s. 14-15], coraz częściej zatrudnieni w różnych niestandardowych formach realizują kluczowe dla organizacji działania, są zatem rdzeniem, a nie peryferiami załogi i w coraz większej liczbie podmiotów większość pracowników stanowią zatrudnieni niestandardowo, co sugeruje, że ich poziom kompetencji i efektywności pracy jest korzystny dla organizacji.

\section{Optymalizacja struktury zatrudnienia w przedsiębiorstwie produkcyjnym - metodyka i wyniki badań}

\subsection{Założenia metodyczne}

Dla wybranego przedsiębiorstwa produkcyjnego, charakteryzującego się wysokimi wahaniami produkcji i mającego doświadczenie w zatrudnianiu pracowników tymczasowych, podjęto próbę wskazania czynników optymalizacji struktury zatrudnienia w odniesieniu do pracowników stałych i tymczasowych. Ze względu na konieczność zachowania poufności wszelkie dane zostały zniekształcone o wybrany i zmienny wskaźnik w taki sposób, aby nie można było powiązać uzyskanych wyników z danymi przedsiębiorstwa, jednocześnie zapewniając spójność uzyskanych wniosków. Jako metodę badawczą przyjęto analizę przypadku z zastosowaniem metod symulacyjnych. Ogólny problem optymalizacji sprowadza się do porównania kosztu zmiennego realizacji określonej skali produkcji w okresie (przy danej zmienności) dla różnej struktury pracowników stałych i tymczasowych. W praktyce odpowiedź na pytanie o strukturę pracowników ma służyć planowaniu zatrudnienia. $\mathrm{W}$ analizie przyjęto za cel identyfikację czynników, które miały wpływ na taką strukturę w latach ubiegłych.

W ramach badania przyjęto następującą procedurę:

1. Wywiady z liderami i kierownikami produkcji.

2. Ustalenie kosztów pracowników tymczasowych i stałych.

3. Wpływ liczby pracowników tymczasowych na uzyskiwane wyniki produkcyjne, $w$ tym:

a) wybór wskaźnika oceniającego wydajność pracowników, 
b) weryfikacja uzyskanych wyników i wyeliminowanie czynników pozostałych.

4. Ustalenie algorytmu optymalizacji.

Do badania wybrano wyodrębnioną grupę linii produkcyjnych charakteryzującą się wysokimi wahaniami produkcji przekraczającymi $20 \%$ (rys. 1). Wstępne wyniki wywiadów wykazały, że, zdaniem kierowników brygad i kadry zarządzającej produkcją pracownicy tymczasowi mają istotnie negatywny wpływ na efektywność linii produkcyjnej. Zgodnie z zadaniem optymalizacyjnym istotne jest zatem porównanie kosztów zatrudniania pracowników własnych i tymczasowych z efektami przez nich uzyskiwanymi i z kosztami niewykorzystania czasu pracy pracowników stałych.

Ze względu na w wspomniane wysokie wahania przedsiębiorstwo zatrudniało pracowników tymczasowych, którzy w badanym okresie (średniomiesięcznie) stanowili nawet ponad 35\% załogi (rys. 2).
Przedsiębiorstwo osiągało elastyczność linii produkcyjnych przez modyfikację systemów pracy. Optymalne wykorzystanie linii produkcyjnych osiągane jest przede wszystkim przez pracę w systemie 3-zmianowym, gdyż praca w systemie 4-brygadowym jest mniej korzystna kosztowo. Jednocześnie firma w okresach wyżu produkcyjnego może uruchomić dodatkową zmianę, a w przypadku niżu ograniczyć zmiany do dwóch lub jednej. Wymagane są jednak wówczas zmiany obsady pracowników - dokonywane są one przez podział brygad pracowników stałych, własnych i uzupełnianie ich pracownikami tymczasowymi.

Nominalna obsada linii wynosi 8,5 osoby netto na zmianę, jednak, biorąc pod uwagę absencję, należy stwierdzić, że zapotrzebowanie na pracowników brutto wynosi 10 osób na zmianę w systemie 3-brygadowym i 11 osób na zmianę w systemie 4-brygadowym. Badaniu poddano lata 2014-2015, jednak ze względu na wpływ innych czynników do analizy przyjęto rok 2015. Średni poziom zatrudnienia na liniach wyniósł 125 osób, w tym 97 pracowników własnych i 28 pracowników tymczaso-

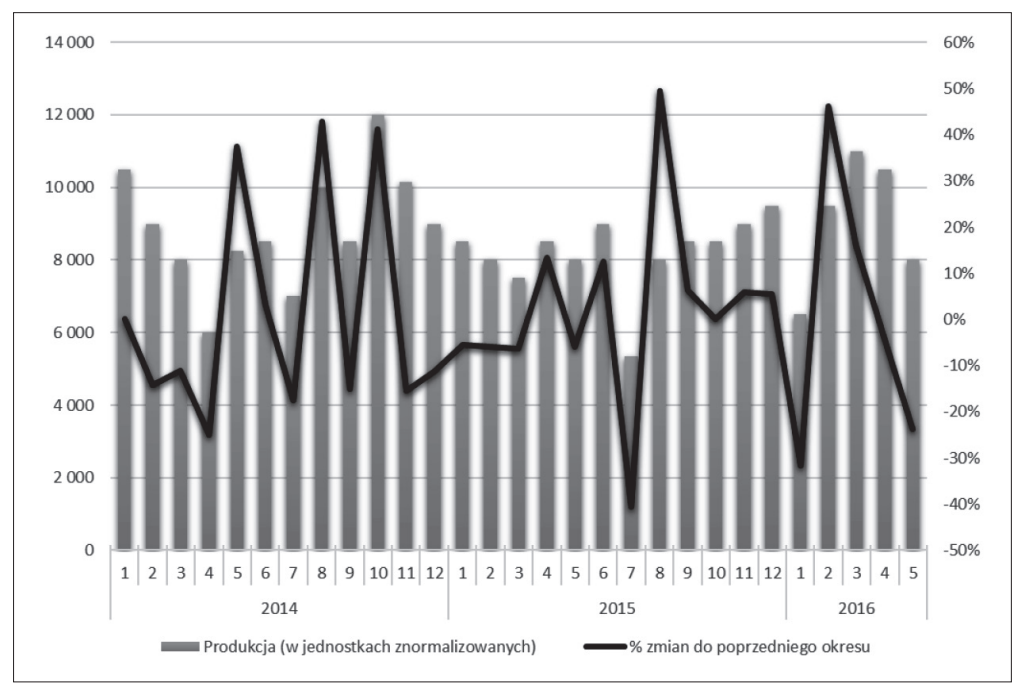

Rysunek 1. Wielkość produkcji w jednostkach znormalizowanych dla wybranej grupy linii produkcyjnych

Źródło: opracowanie własne.

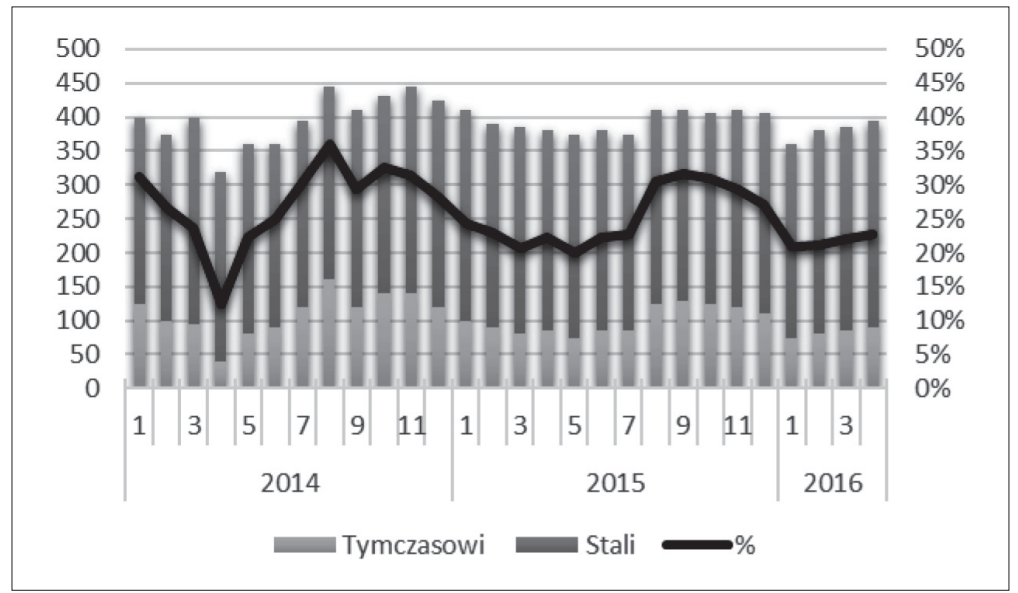

Rysunek 2. Porównanie zatrudnienia pracowników stałych i tymczasowych dla wybranej grupy linii produkcyjnych

Źródło: opracowanie własne. 
wych (w tym 13 osób z doświadczeniem powyżej 180 dni). Dla celów analizy założono, że wymagana elastyczność zatrudnienia realizowana będzie wyłącznie poprzez pracowników tymczasowych z doświadczeniem poniżej $180 \mathrm{dni}$ - podstawy tych założeń przedstawiono poniżej.

\subsection{Koszty zatrudnienia pracowników stałych i tymczasowych}

Zatrudnienie pracowników tymczasowych ma sprzyjać obniżeniu całkowitych kosztów produkcji w danym (niepewnym) okresie, jednocześnie alternatywą pozostaje zatrudnianie odpowiedniej liczby pracowników stałych lub stosowanie takich rozwiązań dotyczących ich czasu pracy, aby umożliwić dostosowanie obecności w pracy do zadań produkcyjnych.

Na rysunku 3 przedstawiono teoretyczny model kosztów elastyczności przy zatrudnieniu stałym.

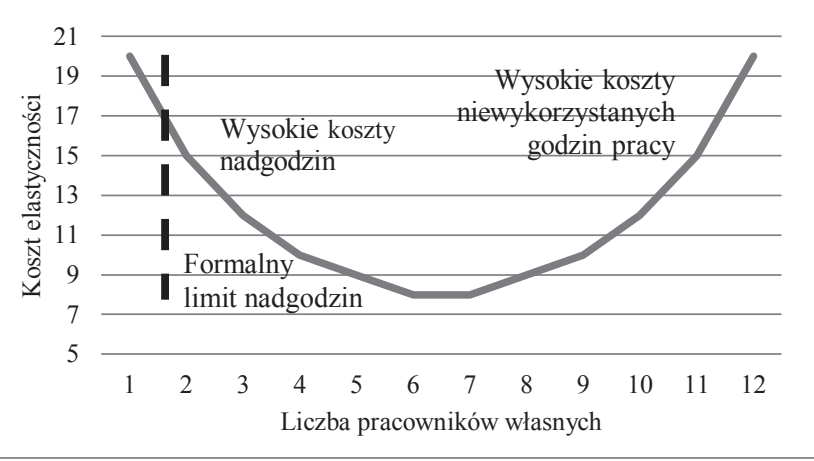

Rysunek 3. Krzywa kosztów elastyczności przy zatrudnieniu stałym

Źródło: opracowanie własne.

Zbyt wysoka liczba pracowników powoduje wysokie koszty niewykorzystanego czasu pracy (w okresach zmniejszonego zapotrzebowania), podczas gdy zbyt niska liczba pracowników wymusza wydłużanie czasu pracy i generuje dodatkowe koszty za czas pracy w godzinach nadliczbowych. Warto zaznaczyć, że istnieją również ograniczenia formalne uniemożliwiające pracę ponad dany limit godzin. Nadmiar nadgodzin wpływa również negatywnie na efekty i atmosferę pracy. Zatrudnianie pracowników stałych na poziomie gwarantującym realizację zadań produkcyjnych w okresie największego zapotrzebowania będzie generowało koszty niewykorzystanego czasu pracy w okresach niższego zapotrzebowania; jednocześnie opcjonalnie wykorzystanie pracowników stałych w okresach szczytu produkcyjnego jest istotnie droższe ze względu na koszt dodatkowego wynagrodzenia za pracę $w$ godzinach nadliczbowych oraz nie zawsze możliwe (ze względu na tygodniowe czy miesięczne limity godzin pracy).

Na potrzeby badania (wykorzystując dane historyczne) określono, że przy danych wahaniach produkcyjnych można wyznaczyć taki poziom zatrudnienia pracowników stałych, aby minimalizować całkowite koszty elastyczności. Przy czym koszty elastyczności określane były jako suma wynagrodzeń za czas niewykorzystany i wynagrodzeń dodatkowych za czas pracy w godzinach nadliczbowych.
Ograniczenie kosztu niewykorzystanych godzin pracy możliwe jest np. przez przydzielanie pracownikom innych obowiązków. W badanym przedsiębiorstwie było to możliwe, jednak osiągana przez pracowników stałych efektywność na innych stanowiskach pracy była bardzo niska i nie stosowano tego rozwiązania w istotnej skali. Z kolei pracownicy tymczasowi (choć nie w badanym przypadku) mogą być drożsi ze względu na przynajmniej dwa czynniki: ich oczekiwania związane z rekompensatą za dostępność i brak stabilności zatrudnienia (w tym przypadku nie zaobserwowano takich sytuacji) oraz koszty (i marżę) organizatora - agencji pracy tymczasowej lub koszty wewnętrznych komórek zajmujących się pozyskaniem pracowników.

Praktyczne rozwiązanie problemu wyznaczenia optymalnej struktury zatrudnienia wymagało przeprowadzenia wielu symulacji i uwzględnienia zmiennych pomijanych przy modelowaniu teoretycznym. Konieczne było obliczenie realnego dostępnego czasu pracy pracowników stałych oraz całkowitego kosztu pracy. Przede wszystkim (dla obu grup pracowników) uwzględniono:

- koszty wynagrodzeń za czas choroby, czas urlopów,

- koszty pozostałych składników wynagrodzeń,

- koszty innych obciążeń formalno-podatkowych związanych z wypłatą wynagrodzeń,

- koszty wdrożenia pracowników tymczasowych (liczone jako koszt wynagrodzenia za godziny, które muszą być poświęcone na przyuczenie nowego pracownika).

Koszt pracy pracowników tymczasowych w badaniu był stosunkowo łatwy do obliczenia, gdyż przedsiębiorstwo korzystało z usług agencji pracy tymczasowej.

W badaniu nie uwzględniono kosztów organizacyjnych (np. kosztów czasu pracy pracownika stałego szkolącego pracownika tymczasowego) czy grupy tzw. kosztów transakcyjnych (np. kosztów zawarcia umowy z agencją pracy tymczasowej czy kosztów koordynacji procesu). Przyjąć należy, że koszty te są kosztami zarządzania - skala korzyści z wdrożenia elastycznych rozwiązań opartych na pracownikach tymczasowych powinna być istotna i rekompensować dodatkowy wysiłek organizacyjny. W badaniu okazało się, że w przeliczeniu na godzinę pracy, przy danej stawce brutto dla pracownika, różnica między całkowitym kosztem pracy pracownika stałego a kosztem pracy pracownika pozyskiwanego z agencji pracy tymczasowej jest rosnąca bardziej proporcjonalnie niż stawka tego pracownika - wynikało to z nieliniowych obciążeń niektórych składników kosztów pracy.

Problem porównania zrodził się również ze względu na różnicę w faktycznym wynagrodzeniu brutto pracowników. Stali pracownicy bezpośrednio produkcyjni zarabiali średnio istotnie więcej niż pracownicy tymczasowi. Wśród pracowników tymczasowych występowały również różnice w wynagrodzeniach ze względu na ich okres zatrudnienia. W wynikach przeprowadzonego badania miało to kluczowe znaczenie, gdyż po uwzględnieniu realnego czasu pracy i realnych kosztów wynagrodzeń (uwzględniających różne stawki) okazało się, że:

- doświadczony pracownik stały jest droższy od pracownika tymczasowego, 
- niedoświadczony pracownik tymczasowy jest droższy od niedoświadczonego pracownika stałego.

\subsection{Wydajność pracowników stałych i tymczasowych}

Przystępując do analizy, przyjęto założenie, że pracownicy tymczasowi ze względu na mniejsze doświadczenie są mniej efektywni niż pracownicy stali. Na ich efektywność wpływa również mniejsza znajomość procesów, produktów czy też niższe zaangażowanie przejawiające się np. mniejszą innowacyjnością. Wstępna analiza danych nie wykazała jednak spodziewanych (istotnych) różnic w efektywności zespołów, w skład których wchodzili pracownicy tymczasowi.

W zadaniu optymalizacyjnym konieczne jest uwzględnienie bezpośredniej wydajności linii produkcyjnej wyrażonej np. sztukami czy kilogramami wyprodukowanych jednostek. W symulacji przeprowadzonej na potrzeby badania okazało się, że porównanie wydajności pracowników stałych i tymczasowych musi uwzględniać odpady produkcyjne. Rozszerzając to spostrzeżenie, dla oceny efektywności pracowników należy uwzględnić również pozostałe aspekty, takie jak jakość, zużycie materiałów i energii czy np. tempo reakcji. Czynniki te w symulacji nie były zastosowane, gdyż nie wpływały na ocenę wydajności całej linii, powinny jednak zostać rozpatrzone w innych zadaniach optymalizacyjnych.

Pewnym wyzwaniem było również wyeliminowanie z oceny efektywności innych czynników, takich jak np. przestoje maszyn (niezawinione przez obsługę), postoje techniczne czy np. (niezależne od pracowników) zmniejszone zamówienia, które bezpośrednio wpływają na ocenę wydajności pracy pracowników (wydajność obsługiwanego przez nich procesu). W badaniu zastosowano wskaźnik LOE (Line Overall Effectiveness - liczba wyprodukowanych dobrych produktów w odniesieniu do teoretycznej liczby produktów, jakie można byłoby wyprodukować w określonej jednostce czasu) określający całkowitą efektywność wyposażenia. Wskaźnik ten bierze pod uwagę do- stępność maszyn, ich wydajność i osiąganą jakość. Na potrzeby symulacji zależności te zostały jednak zmodyfikowane $w$ taki sposób, aby ocenić skorygowaną o jakość (i odpad) wydajność w relacji do dostępnego czasu - metoda ta była stosowana do oceny linii produkcyjnych i podejmowania innych decyzji zarządczych.

Początkowe testy tak sprecyzowanego algorytmu nie dały pełnych rezultatów. Okazało się, że w jednym z badanych lat nie odnotowano zależności między wskaźnikiem LOE a liczbą pracowników tymczasowych. Przyczyną okazały się zmiany technologiczne, które wpłynęły na efektywność wszystkich brygad, a jednocześnie wprowadzono je w okresie, w którym zatrudniano mniej pracowników tymczasowych. Porównanie wyników miesięcznych: zależności produktywności wyrażonej wskaźnikiem LOE do liczby pracowników tymczasowych, również nie pozwoliło na zaobserwowanie istotnych statystycznie relacji. Skorygowano zatem badania i rozdzielono okresy badania na tygodniowe - przyjmując założenie średniotygodniowej zmienności struktury zatrudnienia; jednocześnie ponowiono również badania, uwzględniając zmienność dzienną, co pozwoliło na rozszerzenie próby i bardziej precyzyjne wyniki.

Otóż nie zawsze tymczasowa forma zatrudnienia determinowała mniejsze doświadczenie pracownika i potencjalnie niższą efektywność - co założono po wstępnych wywiadach z kierownikami. Istotne znaczenie miała struktura zatrudnienia pracowników tymczasowych według ich stażu pracy (rys. 4). Na badanych stanowiskach pracy zaobserwowano, że pracownicy pracujący ponad 180 dni częściej byli wybierani do obsady zespołów niż pracownicy z krótszym stażem. Wynikało to z faktu, że w okresach krótkotrwałych spadków produkcji w pierwszej kolejności redukowani byli pracownicy z najmniejszym stażem.

W związku z taką strukturą badaniu poddano wpływ liczby pracowników tymczasowych z doświadczeniem ponad 180 dni na efektywność brygad obsługujących linie produkcyjne. W wyniku analizy zaobserwowano, że nie ma istotnej zależ-

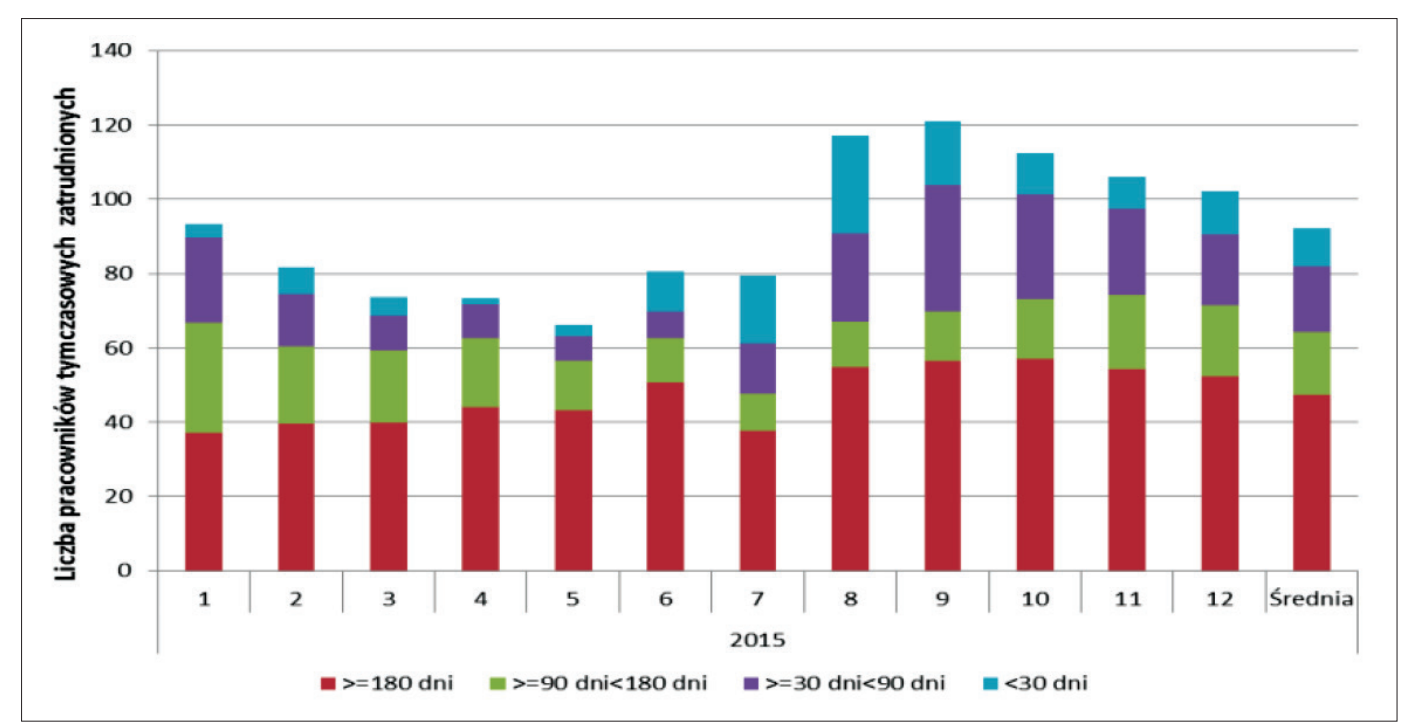

Rysunek 4. Liczba pracowników tymczasowych według okresu zatrudnienia w dniach

Źródło: opracowanie własne. 
ności pomiędzy liczbą pracowników tymczasowych posiadających doświadczenie powyżej $180 \mathrm{dni}$ a wynikami produkcyjnymi, co potwierdza obserwację kierownictwa wydziału (na rys. 5 punkty na teście Tukeya są zbliżone do zera - różnice widoczne są tylko dla 4 pracowników, ale w tym wypadku liczba próbek jest zbyt mała).

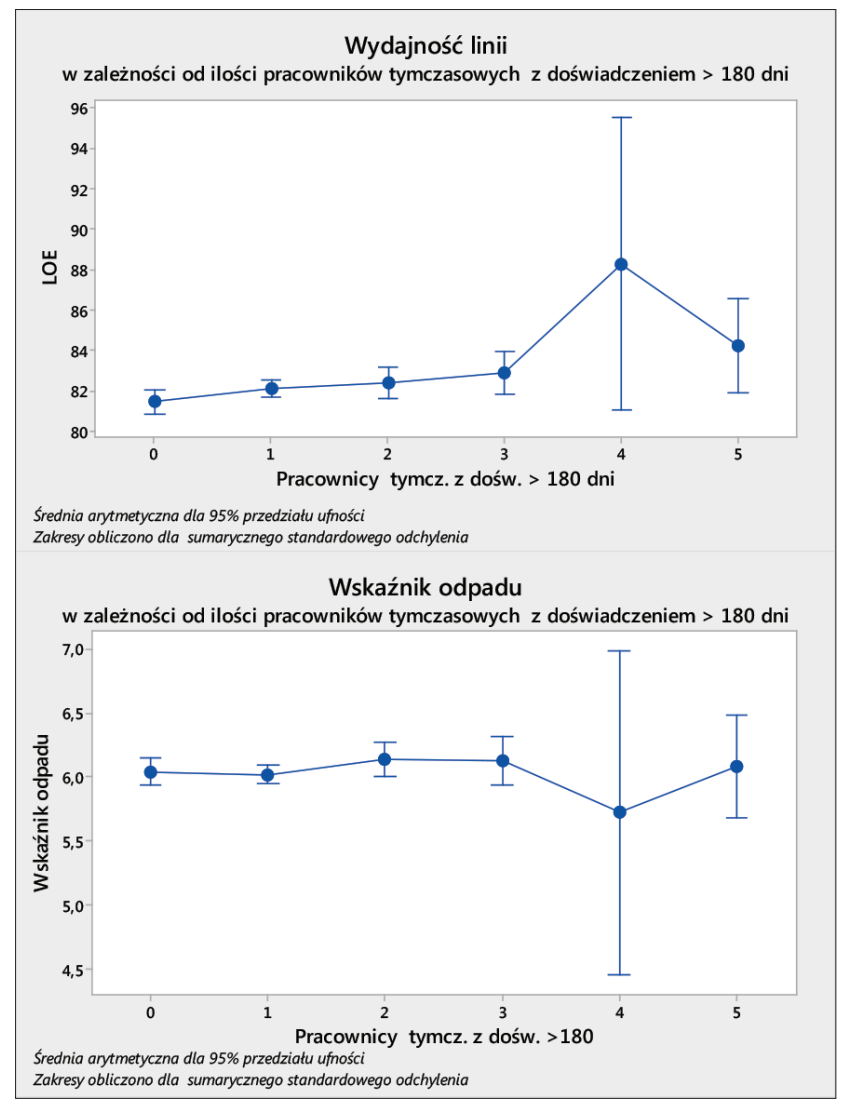

Rysunek 5. Zależność wydajności linii i poziomu odpadu od liczby pracowników tymczasowych z doświadczeniem powyżej 180 dni

Źródło: opracowanie własne.

Zatem szacując efektywność pracy pracowników tymczasowych, należy uwzględnić, że pracownik, który pracuje dłuższy czas lub jest zatrudniany kolejny raz, może dorównać efektywnością pracownikowi stałemu. Długość doświadczenia koniecznego do osiągnięcia zbliżonego poziomu efektywności zależy od specyfiki stanowiska pracy i wstępnego przygotowania pracownika, jednak można przyjąć pewne standaryzowane założenia. Należy zaznaczyć, że o ile doświadczony pracownik tymczasowy może pracować równie wydajnie, o tyle nie zawsze $\mathrm{w}$ pełni zastąpi pracownika stałego, np. w zakresie zdolności czy chęci zgłaszania możliwych usprawnień. Powyższa zależność w badanym przykładzie spowodowała również dodatkowe (nieprzewidziane) zachowania kierowników, którzy dążyli do zatrzymywania tymczasowych pracowników doświadczonych nawet w okresach spadku produkcji. Miało to im zapewnić większą efektywność pracowników w okresach wzrostu, z drugiej strony - ograniczało poziom elastyczności.

W analizowanej grupie linii produkcyjnych w największej liczbie przypadków obsady linii pracowały z jednym, dwoma lub trzema pracownikami tymczasowymi (rys. 6). Sytuacje, w których w obsadach występowało więcej niż czterech pracowników zewnętrznych, miały miejsce tylko w przypadku największych pików produkcji, kiedy uruchamiane były dodatkowe brygady. Jeszcze rzadziej zdarzało się, aby występowała większa liczba pracowników niedoświadczonych. Na przykład w ponad 1000 przypadkach zmian produkcyjnych (30\% całości) nie pracował żaden pracownik z doświadczeniem krótszym niż 180 dni.

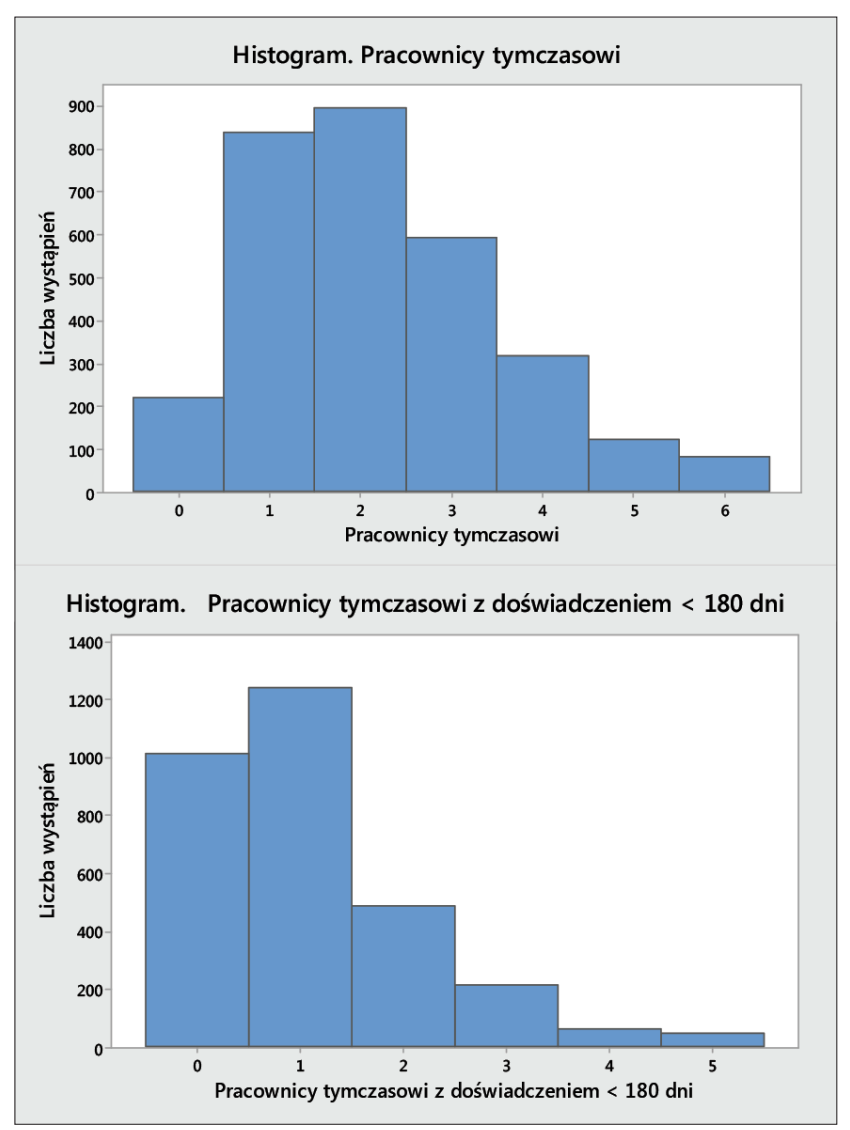

Rysunek 6. Histogram liczby pracowników tymczasowych w obsadach linii produkcyjnej

Źródło: opracowanie własne.

Jednym z kluczowych wniosków było zatem zdefiniowanie „pracownika tymczasowego”. W analizie produktywności pracowników tymczasowych przyjęto założenie, że pracownikiem tymczasowym będzie ten pracownik zatrudniony przez zewnętrzną agencję, który przepracował mniej niż 180 dni. Przy takim założeniu zależności między liczbą pracowników tymczasowych a wydajnością i ilością odpadu są istotne (rys. 7).

W przypadku wydajności linii wyniki dla 1-2 pracowników są bardzo zbliżone, natomiast przy obsadzie składającej się z większej ich liczby widać znaczne pogorszenie wyników. W przypadku poziomu odpadu takie pogorszenie zauważalne jest powyżej średnio 4 pracowników tymczasowych.

W praktyce okazało się, że liczba zmian (brygad), dla których w obsadzie występują więcej niż dwie osoby niedoświadczone, jest nieduża (w badanym roku wystąpiła jedynie w 109 przypadkach - w okresach największych pików produkcyjnych lub w sytuacjach awaryjnych (np. nagła absencja). 


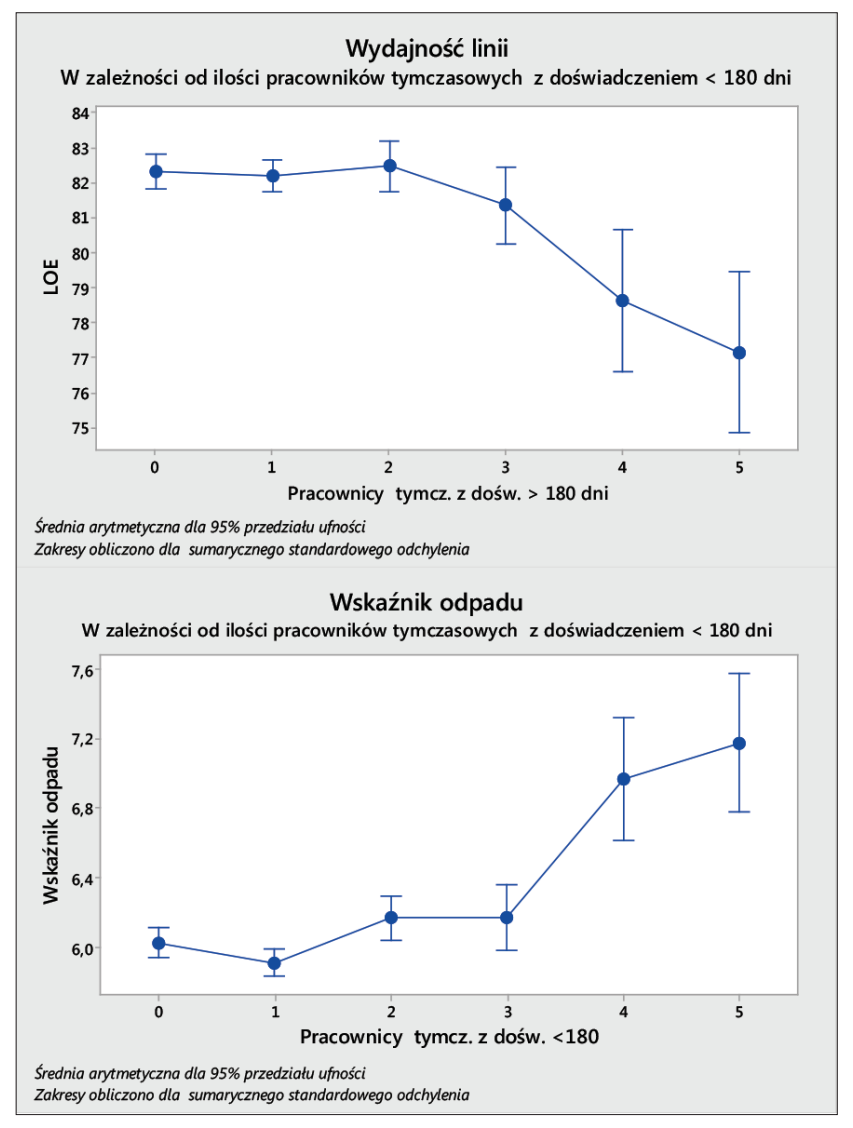

Rysunek 7. Zależność wydajności linii i poziomu odpadu od liczby pracowników tymczasowych z doświadczeniem poniżej 180 dni

Źródło: opracowanie własne.

Według opinii kierownika konfrontującego uzyskane wyniki błędy ludzkie miały zdecydowanie większy wpływ na odpad niż na pozostałe czynniki obniżające poziom dobrej produkcji. W większości na produktywność linii wpływ miały awarie. Główne procesy technologiczne są nadzorowane przez pracowników stałych, którzy dbają o ich poprawność. Dlatego zrozumiały wydaje się większy wpływ pracowników tymczasowych na poziom odpadu niż na uzyskiwaną wydajność linii. Dalsza analiza wydajności w odniesieniu do liczby odpadów pozwoliła na identyfikację innych (poza strukturą pracowników) czynników wpływających na osiągane efekty: były to same linie produkcyjne (pozornie bliźniacze), numery zmian (pora dnia zmiany), liczba produkowanych elementów. Skala różnic wynikająca z obsady linii była jednak zbliżona, zatem tych czynników dalej nie analizowano.

Podsumowując dokonane analizy, można stwierdzić, że pracownicy zatrudnieni przez agencje pracy tymczasowej, którzy mają ponadpółroczne doświadczenie, nie wpływają negatywnie na uzyskiwane rezultaty. W przypadku pracowników z mniejszym stażem wydajność linii i poziom odpadu nie ulegają pogorszeniu, jeżeli ich liczba wynosi około 18-24\% składu zespołu. W przypadku większej liczby następuje widoczne pogorszenie wyników.

\subsection{Kluczowe czynniki optymalizacji zatrudnienia - wnioski i dyskusja}

Przeprowadzone analizy struktury zatrudnienia pracowników stałych i tymczasowych w odniesieniu do kosztów pracy oraz wydajności pracy w obu grupach pracowników pozwalają na sformułowanie kilku zaskakujących wniosków. Po pierwsze, koszty pracy kształtują się w badanej organizacji odwrotnie, niż generalnie zakłada się $\mathrm{w}$ odniesieniu do pracy tymczasowej, tzn. pracownik tymczasowy jest tańszy niż pracownik stały. Taki rozkład może wynikać z różnic kompetencji pracowników lub charakterystyki lokalnego rynku pracy - niemniej stanowi to istotny czynnik, który powinien być brany pod uwagę w planach.

Drugi wniosek dotyczy aspektu zespołowości w kontekście wydajności pracy i konieczności rozróżnienia wydajności indywidualnej i grupowej. W analizowanym przypadku okazało się, że produktywność danego zespołu zależy od liczby pracowników tymczasowych, ale mały ich udział nie obniża wydajności zespołu, nawet jeśli mają mniejsze doświadczenie zawodowe mierzone stażem pracy w danym przedsiębiorstwie i mniejszą wydajność indywidualną.

Tym samym nawiązuje to do trzeciego wniosku, który pozwolił na zidentyfikowanie ważnego czynnika optymalizacji, jakim jest doświadczenie pracownika tymczasowego. Okazało się, że odpowiednie doświadczenie (wyrażone stażem) pozwala na zrównanie kompetencji pracownika tymczasowego ze stałym. To koresponduje ze wskazaną w punkcie 2 niniejszego artykułu tendencją wzrostową $\mathrm{w}$ zakresie wykorzystania pracowników tymczasowych o długim stażu pracy do zadań wymagających dużych kompetencji i związanych z trzonem załogi.

Prezentowane wnioski ze względu na przyjętą metodę mają z pewnością pewne ograniczenia i nie pozwalają na daleko idące uogólnienia czy stworzenie uniwersalnego modelu optymalizacji. Identyfikacja ważnych czynników optymalizacji przybliża jednak do poznania tego złożonego zagadnienia.

\section{Zakończenie}

Problem elastycznego zarządzania zasobami ludzkimi w analizowanym przedsiębiorstwie oparty został na fluktuacyjnym modelu polityki kadrowej bazującym na elastyczności zewnętrznej. Taka praktyka oznacza nieco doraźne działania przedsiębiorstwa, strategicznie postrzegane dotychczas raczej jako restrukturyzacja naprawcza niż optymalizacja rozwojowa [Marciniak 2009]. Jednak nieustający wzrost wykorzystania pracy tymczasowej wskazuje, że takie praktyki nabierają strategicznie pozytywnego znaczenia: uelastyczniają nie tylko liczbowo, ale też funkcjonalnie załogę, która w dodatku nie otrzymuje dużo niższego wynagrodzenia i nie ma dużo niższych kompetencji niż pracownicy stali, wręcz pracownik długotrwale tymczasowy to praktycznie stały. Wychodząc poza granice organizacji, albo raczej rozszerzając je w kontekście rynku pracy, należy stwierdzić, że wykorzystanie pracy tymczasowej może nie tylko stać się punktem wyjścia do stałego, w dotychczasowym rozumieniu, zatrudnienia, ale też sposobem na aktywizację zawodową i budowanie doświadczenia zawodowe- 
go. Praca tymczasowa traktowana jest jednak jako utrwalająca prekaryjny rynek pracy, co wywołuje dążenie do prawnego regulowania tej formy zatrudnienia z różnym dla rynku pracy i przedsiębiorstw skutkiem. Ta problematyka dotyka kolejnego obszaru, jakim jest znaczenie uwarunkowań prawnych wykorzystania pracy tymczasowej i substytucyjność względem niej innych niestandardowych form zatrudnienia [Cahuc, Charlot, Malherbet 2012; Cappellari, Dell'Aringa, Leonardi 2012]. Interesującym dalszym krokiem badawczym byłoby zatem zbudowanie modelu optymalizacji struktury zatrudnienia pracowników stałych i tymczasowych zakładającego nie tylko czynniki wewnętrzne, ale także zewnętrzne działalności organizacji.

\section{Literatura}

Armstrong M., 2005, Zarządzanie zasobami ludzkimi, Oficyna Ekonomiczna, Kraków.

Bąk-Grabowska D., 2016, Zarządzanie zasobami ludzkimi w warunkach stosowania niestandardowych form zatrudnienia, Wydawnictwo Uniwersytetu Ekonomicznego we Wrocławiu, Wrocław.

Cahuc P., Charlot O., Malherbet F., 2012, Explaining the Spread of Temporary Jobs and its Impact on Labor Turnover, Institute for the Study of Labor, Bonn, Discussion Paper no. 6365, http://ftp.iza. org/dp6365.pdf

Cappellari L., Dell'Aringa C., Leonardi M., 2012, Temporary Employment, Job Flows and Productivity: A Tale of Two Reforms, Institute for the Study of Labor, Bonn, Discussion Paper no. 6526, http:// ftp.iza.org/dp6526.pdf.

De Toni A., Tonchia S., 1998, Manufacturing flexibility: a literature review, International Journal of Production Research, vol. 36, no. 6, s. $1588-1589$.

Eapen G., 2010, Flexibility. Flexible Companies for the Uncertain Worlds, CRC Press, Boca Raton.

Golden W., Powell P., 2000, Towards a Definition of Flexibility: in Search of the Holy Grail?, Omega - The International Journal of Management Science, vol. 28, no. 4.

Gołaszewska-Kaczan U., 2013, Praca tymczasowa w polskich warunkach, Studia Ekonomiczne, Uniwersytet Ekonomiczny w Katowicach, Katowice.
Johnson J.L., Lee R.P., Saini A., Grohmann B., 2003, Market-focused strategic flexibility conceptual advances and an integrative model, Journal of the Academy of Marketing Science, 31, s. 74-89.

Juchnowicz M., 2016, Elastyczne zarządzanie kapitałem ludzkim z perspektywy interesariuszy, PWE, Warszawa.

Kasiewicz S., Ormińska J., Rogowski W., Urban W., 2009, Metody osiagania elastyczności przedsiębiorstw, SGH, Warszawa.

Krupski R. (red.), 2005, Zarządzanie przedsiębiorstwem w turbulentnym otoczeniu, $\mathrm{PWE}$, Warszawa.

Leighton P., Syrett M., Hecker R., Holland P., 2014, Nowoczesne formy zatrudnienia, Oficyna a Wolters Kluwer business, Warszawa.

Makowski D., 2006, Praca tymczasowa jako nietypowa forma zatrudnienia, Difin, Warszawa

Marciniak J., 2009, Optymalizacja zatrudnienia, Oficyna a Wolters Kluwer business, Kraków.

Praca tymczasowa, pobrane 6 grudnia 2017 z: http://www.polskieforumhr.pl/praca-tymczasowa.

Rynek agencji pracy tymczasowej 2016, Polskie Forum HR, pobrane 6 grudnia 2017 z: http://www.polskieforumhr.pl/.

Sajdak M., 2015, The Concept of an Agile Enterprise Research Model., International Journal of Social, Behavioral, Educational, Economic and Management Engineering, 6, s. 1764-1769.

Skowron-Mielnik B., 2012, Elastyczna organizacja pracy $w$ przedsiębiorstwie, Wydawnictwo Uniwersytetu Ekonomicznego w Poznaniu, Poznań.

Sushil, Connell J., Burgess J., 2016, Flexible Work Organizations: The Challenges of Capacity Building in Asia, Springer India.

Trzcieliński S., 2011, Przedsiębiorstwo zwinne, Wydawnictwo Politechniki Poznańskiej, Poznań.

Ustawa z dnia 9 lipca 2003 r. o zatrudnianiu pracowników tymczasowych, Dz.U., nr 116, poz. 1608 z późn. zm.

Volberda H.W., 1998, Building the Flexibility Firm. How to Remain Competitive, Oxford University Press, New York.

Zhang Z., Sharifi H., 2001, Agile manufacturing in practice, Application of a methodology, International Journal of Operations \& Production Management, vol. 21 no. 5/6, 2001, pp. 772-79. 